[Review Paper]

\title{
Innovative Methane Conversion Technology Using Atmospheric Pressure Non-thermal Plasma
}

\author{
Tomohiro NOZAKI* and Ken OKAZAKI \\ Dept. of Mechanical and Control Engineering, Tokyo Institute of Technology, 2-12-1 O-okayama, Meguro-ku, Tokyo 152-8552, JAPAN
}

(Received November 9, 2010)

\begin{abstract}
Non-thermal plasma assisted methane reforming is reviewed. Plasma catalysis is one of the innovative next generation green technologies that may meet the needs for energy and materials conservation as well as environmental protection. Non-thermal plasma uniquely generates reactive species independently of reaction temperature, and these species are used to initiate chemical reactions at unexpectedly lower temperatures than normal thermochemical reactions. Non-thermal plasma thus broadens the operation window of existing chemical conversion processes, and ultimately allows modification of the process parameters to minimize energy and material consumption. The general aspects of plasma assisted fuel reforming including arc plasma to non-thermal plasma are described. We specifically focus on dielectric barrier discharge (DBD) as one of the viable non-thermal plasma sources for practical fuel reforming. Two contrasting approaches of DBD-oriented plasma catalysis of methane are introduced: $(1)$ Low temperature $\left(300-500^{\circ} \mathrm{C}\right)$ methane steam reforming using a plasma-catalyst hybrid reactor, and (2) Room temperature direct methane conversion to methanol using a microplasma reactor. The practical background and unique characteristics of each application such as the plasma-catalyst synergistic effect and highly non-equilibrium product distribution are explained.
\end{abstract}

\section{Keywords}

Plasma, Microreactor, Synergy, Non-equilibrium, Methane, Methanol

\section{Introduction}

Current industrial material and energy conversion technology is based on thermochemical processes including various catalytic reactions. Present industry scale technology and related science is well established, but further improvements in energy efficiency and material saving are required. Drastic reductions in $\mathrm{CO}_{2}$ emissions are also important with the growing concern for energy and environmental issues. Green chemistry is a rapidly growing field of science and technology, and often emphasizes renewable bioenergy, bioprocesses, and solar photocatalysis of water splitting and $\mathrm{CO}_{2}$ regeneration to provide synthetic fuels. Plasma catalysis of hydrocarbon feedstocks is also an important component of innovative next generation green technologies that are expected to satisfy the needs for energy saving, environment protection, and resource conservation ${ }^{1) \sim 4 \text { ). }}$. Non-thermal plasma has the specific characteristic of generating reactive species almost independently of reaction temperature. Such plasma-generated reactive species are used to initiate chemical reactions at much lower temperatures than the corresponding normal

\footnotetext{
* To whom correspondence should be addressed.

* E-mail: tnozaki@mech.titech.ac.jp
}

thermochemical reactions. Therefore, non-thermal plasma extends the operation window of existing chemical conversion processes, which will ultimately enable better control over the process parameters to save energy and resources, and to protect the environment.

This review briefly describes the general aspects of plasma fuel reforming from high temperature arc plasma to cold non-thermal plasma. Various plasma sources are available, but this review specifically focuses on dielectric barrier discharge (DBD) as one of the most viable non-thermal plasma sources for practical fuel reforming. First, elementary electron collision processes in non-thermal plasma are briefly introduced for those who may not be familiar with plasma chemistry. Two contrasting approaches of DBD-oriented plasma catalysis of methane, based on our work, are then introduced: (i) Low temperature $\left(300-500^{\circ} \mathrm{C}\right)$ methane steam reforming using a DBD-catalyst hybrid reactor used for profitable recovery of bio-resources, and (ii) Direct conversion of methane to methanol at room temperature using a microplasma reactor, providing flexible solutions to future $\mathrm{C}_{1}$ chemistry. Both the practical background and the mechanistic aspects of plasma catalysis such as plasma-catalyst synergistic effect and highly non-equilibrium product distribution are described. Finally, future trends are discussed. 

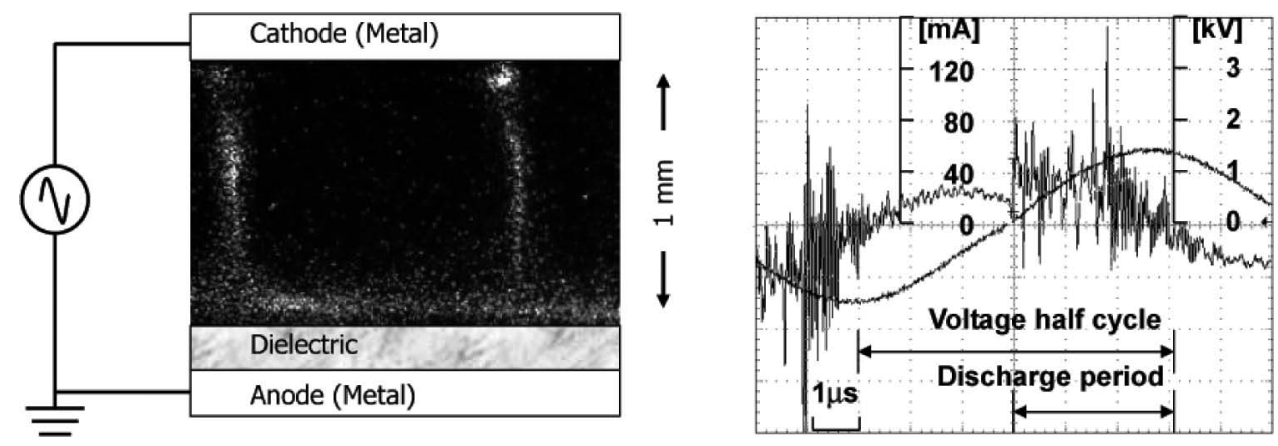

A narrow filamentary discharge channel is created at the gap (left).

Voltage and current waveforms $(80 \mathrm{kHz}$ AC) (right).

Fig. 1 Snapshot of DBD Produced in Pure Methane at $20^{\circ} \mathrm{C}$ (10 ns exposure time)

\section{Plasma Assisted Fuel Reforming}

\subsection{Overview of Plasma Sources for Fuel Conversion}

Plasma sources can be divided into three types based on the purpose of fuel reforming: First example is low gas temperature non-thermal plasma such as dielectric barrier discharge (DBD), corona discharge, and spark discharge ${ }^{5}$. Low gas temperature non-thermal plasma consists of partially ionized gas, in which the gas temperature remains near room temperature, is readily created using a simple electrode configuration and inexpensive power source. Reactive species produced by electron impact are extremely important in fuel conversion processes. Gaseous feedstocks or light liquid fuels, after vaporization, are used as the initial feedstocks. The second example is the arc plasma where high temperature thermal energy is essential to decompose carbon containing complex materials into basic elements such as hydrogen and carbon monoxide. Arc plasma has been historically used for acetylene synthesis $^{6)}$ and hydrogen and carbon black co-production ${ }^{7)}$. Recent applications of arc plasma have focused on gasification of biomass, coal, and municipal waste to produce syngas due to the increasing concern for energy and environmental issues. The third example is relatively new, and known as "warm discharge" definition of warm discharge is not clear, but may be characterized as non-thermal (cold) plasma generated in a relatively high temperature gas media. Warm discharge focuses on the combination of radical species created by non-thermal plasma and thermal energy to improve chemical conversion efficiency. Gliding arc and related technology is frequently used for this purpose ${ }^{8), 9)}$. The thermal energy is supplied either by the plasma, heat released by exothermic reactions such as partial oxidation, or external waste heat via an appropriate heat exchanger. Thermal energy is partly recovered through endothermic reactions such as steam reforming to enhance overall energy and material conversion effi- ciency. We have been focusing on DBD exclusively as one of the viable plasma sources for fuel reforming due to its flexibility and better controllability compared with other plasma sources.

\section{2. Dielectric Barrier Discharge (DBD)}

DBD, corona discharge, and spark discharge are commonly used for fuel reforming ${ }^{5)}$, but we exclusively used DBD due to several reasons. First, DBD has a long history originating in ozone synthesis, so the fundamental physical and chemical properties, and industrial installation requirements are well understood ${ }^{10)}$. Second, non-thermal plasma is readily generated: DBD rarely transits to unstable spark or arc plasma due to the presence of the dielectric barrier in the gap. Finally, electrode and reactor configurations allow great flexibility: Combination of DBD and functionalized porous media such as reforming catalysts has been rapidly growing since $2000^{2)}$. The reactor can be also constructed with inexpensive materials such as glass and polymers. A peculiarity of DBD is the presence of dielectric insulator on one or both metallic electrodes, which leads to the formation of numerous filamentary microdischarges of nanosecond duration. Figure 1 shows the typical voltage and current waveforms observed in methane-fed $\mathrm{DBD}^{11)}$ as well as an image of the microdischarge taken with a high-speed intensified CCD camera with 10 ns exposure time (i-Star DH712; Andor Technology). A number of nanosecond current pulses with 1-10 ns duration are observed during every half cycle of applied voltage. The immediate termination of the developing discharge as a result of charge built up on the dielectric barrier creates highly reactive non-equilibrium conditions at atmospheric pressure. Because of the charge accumulation on the barrier, microdischarges are dispersed randomly between the electrodes, providing a wide range of ionizing discharge gaps in time and space average. Although DBD in air has been studied extensively for ozone synthesis ${ }^{10)}$, limited information is available for methane-fed DBD. Detailed gas phase plasma chemistry of methane-fed 


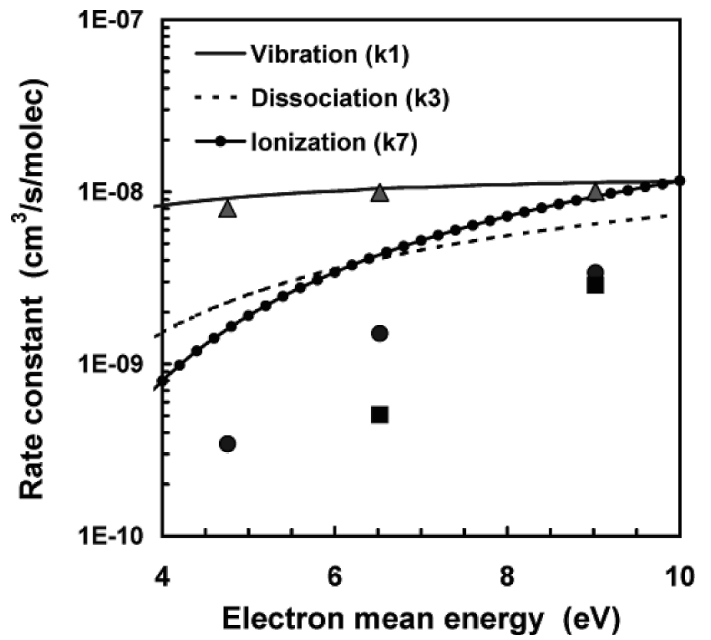

Solid- and dotted-line indicate Boltzmann rate constants and $\boldsymbol{\Delta}(k 1)$, (k3), ( $(k 7)$ indicate non-Boltzmann rate constants.

Fig. 2 Boltzmann and Non-Boltzmann Rate Constants for Electron and Methane Collision $\left(100 \mathrm{kPa}, 20^{\circ} \mathrm{C}\right)$

DBD has been described previously ${ }^{12), 13)}$.

\section{3. Elementary Collision Process between Electron and Methane}

The reaction rate for electron impact excitation of methane is expressed as follows:

$$
-\frac{\mathrm{d}\left[\mathrm{CH}_{4}\right]}{\mathrm{d} t}=k \cdot \mathrm{Ne} \cdot\left[\mathrm{CH}_{4}\right]
$$

Here, $k$ is the rate constant $\left(\mathrm{cm}^{3} / \mathrm{s} / \mathrm{molec}\right)$, and $N e$ is the electron density $\left(\mathrm{molec} / \mathrm{cm}^{3}\right)$. Electron density in a single filamentary discharge formed in air, for example, is approximately $10^{14} \mathrm{~cm}^{-314}$. $\quad k$ is estimated using the Eq. (2):

$$
k=\int \sigma(E) \cdot v \cdot f(E) \mathrm{d} E
$$

Here, $\sigma(E)$ is the electron-methane collision cross section, $E$ is the electron energy, $v$ is the electron drift velocity, and $f(E)$ is the electron energy distribution function (EEDF). EEDF is a function of temperature, pressure, type of gas, and electric field, and incorporates a large displacement from the Boltzmann distribution, so the Boltzmann equation for practical EEDF must be solved under given conditions to evaluate the appropriate rate constant. Assuming the standard conditions of methane (298 K and $101 \mathrm{kPa})$, EEDF and other swarm parameters were calculated using ELENDIF software that solves the time evolution of the electron energy distribution function using two-term spherical harmonic expansion of the Boltzmann transport equation ${ }^{16)}$. Assuming Boltzmann and nonBoltzmann electron energy distribution functions, rate constants for vibrational $(k 1)$, dissociation $(k 3)$ and ionization $(k 7)$ collisions ${ }^{15)}$ were calculated as shown in Fig. 2 (see also Table 1). There is a small deviation
Table 1 Eight Elementary Processes Considered in Fig. 2

\begin{tabular}{clcl}
\hline & \multicolumn{1}{c}{$\mathrm{CH}_{4}+\mathrm{e}$} & Threshold $[\mathrm{eV}]$ & \multicolumn{1}{c}{ Process } \\
\hline$k 1$ & $\rightarrow \mathrm{CH}_{4}\left(v_{24}\right)+\mathrm{e}$ & 0.162 & bending \\
$k 2$ & $\rightarrow \mathrm{CH}_{4}\left(v_{13}\right)+\mathrm{e}$ & 0.361 & stretching \\
$k 3$ & $\rightarrow \mathrm{CH}_{3}+\mathrm{H}+\mathrm{e}$ & 9.0 & dissociation \\
$k 4$ & $\rightarrow \mathrm{CH}_{2}+\mathrm{H}_{2}+\mathrm{e}$ & 10.0 & dissociation \\
$k 5$ & $\rightarrow \mathrm{CH}+\mathrm{H}_{2}+\mathrm{H}+\mathrm{e}$ & 11.0 & dissociation \\
$k 6$ & $\rightarrow \mathrm{C}+2 \mathrm{H}_{2}+\mathrm{e}$ & 12.0 & dissociation \\
$k 7$ & $\rightarrow \mathrm{CH}_{4}^{+}+\mathrm{e}+\mathrm{e}$ & 12.6 & ionization \\
$k 8$ & $\rightarrow \mathrm{CH}_{3}^{+}+\mathrm{H}+\mathrm{e}+\mathrm{e}$ & 14.3 & ionization \\
\hline
\end{tabular}

for vibrational excitation because the excitation threshold $(0.16$ and $0.36 \mathrm{eV})$ is small enough that electron energy distribution and vibrational cross section overlap considerably; therefore, vibrational excitation rate constants can be estimated by assuming the Boltzmann EEDF. However, the Boltzmann EEDF overestimates the non-Boltzmann rate constants for dissociation and ionization, although the electron mean energy is identical for both cases. Electrons at the high energy tail of EEDF can cause dissociation and ionization of methane, and lose energy through those collisions. As a result, the probability of the presence of high energy electrons decreases, so the rate constants with experimental EEDF are smaller than those estimated with the Boltzmann EEDF. The gas translational temperature represents the mean energy of the molecules that dominate chemical reactions. In contrast, the small number of electrons at the high energy tail of the EEDF dominates ionization phenomena in non-thermal plasma. The electron density is multiplied exponentially by the "electron avalanche" phenomenon, so even a trace amount of energetic electrons is sufficient to establish gas breakdown.

\section{4. Comparison between Thermal Energy and} Non-thermal Plasma Excitation of Methane

The rate-determining step of methane conversion is dissociation of the strong $\mathrm{C}-\mathrm{H}$ bond. Here, three different approaches are compared: R1, homogenous gas phase reaction; R2, heterogeneous surface reaction; and R3, plasma-enhanced reaction.

$$
\begin{aligned}
& \mathrm{CH}_{4}(+ \text { thermal energy })=\mathrm{CH}_{3}+\mathrm{H} \quad \mathrm{E} 1=434 \mathrm{~kJ} / \mathrm{mol} \\
& \mathrm{CH}_{4}(+\mathrm{Ni})=\mathrm{CH}_{3}{ }^{*}+\mathrm{H}^{*} \quad \mathrm{E} 2=100 \mathrm{~kJ} / \mathrm{mol} \\
& \mathrm{CH}_{4}+\mathrm{e}=\mathrm{CH}_{3}+\mathrm{H}+\mathrm{e} \quad \mathrm{E} 3=868 \mathrm{~kJ} / \mathrm{mol}
\end{aligned}
$$

E1-E3 express activation energy and superscript “*” denotes chemisorbed fragments. The activation energy for methane pyrolysis (R1) is $434 \mathrm{~kJ} / \mathrm{mL}^{17)}$ so requires high temperature thermal energy $\left(>1000^{\circ} \mathrm{C}\right)$. The activation energy and the reaction temperature are greatly reduced by the use of transition metal catalysts (R2) ${ }^{18)}$. A peculiarity of non-thermal plasma is that chemically stable methane is dissociated by electron impact almost independently of reaction temperature, but inelastic electron collision requires a large activation energy ${ }^{15)}$. Compared to the endothermic enthalpy of methane dis- 
sociation, approximately $50 \%$ of the electronic energy fed into methane is inevitably wasted via molecular collision which is eventually dissipated as heat. Consequently, the energy efficiency of electronic methane dissociation is generally low.

To enhance the energy conversion efficiency of nonthermal plasma fuel reforming, we have proposed two processes. Firstly, low temperature $\left(300-500^{\circ} \mathrm{C}\right)$ methane steam reforming using a DBD-catalyst hybrid reaction: Reactive species created by DBD remarkably enhance methane conversion efficiency in the presence of reforming catalysts due to the synergistic effects between the catalyst and DBD. Secondly, direct methane conversion to methanol using a microplasma reactor: highly non-equilibrium product distribution is obtainable via room temperature methane partial oxidation. Although the electrical properties of DBD in those applications are more or less similar, the effect of DBD on methane conversion is very different in terms of thermal energy.

\section{Endothermic Reaction System: Methane Steam Reforming Using DBD-catalyst Hybrid Reaction}

\section{1. Introduction}

The primary role of a non-thermal plasma is to generate reactive species at the lowest reasonable temperature possible. The reactive species are used to initiate chemical reactions at low temperature or to create unusual reaction pathways which result in non-equilibrium product distributions at a given temperature and pressure. Therefore, non-thermal plasma can enable better process control over operating parameters. However, radical injection is not satisfactory to enhance energy and material conversion efficiency if non-thermal plasma is combined with endothermic reactions such as steam reforming. Therefore, for conservation of energy, thermal energy must be supplied simultaneously. Without appropriate combination with thermal energy, non-thermal plasma cannot promote the overall chemical conversion process. In this section, the DBDcatalyst hybrid reaction for the low temperature (300$500^{\circ} \mathrm{C}$ ) methane steam reforming is discussed. Appropriate combination of DBD and low temperature thermal energy is the key to establish an economically viable plasma fuel conversion process.

\section{2. Background of the Project}

This project was initiated to develop profitable recovery of methane from poor bio-resources using nonthermal plasma technology. Biogas generally consists of $60 \%$ methane and $40 \% \mathrm{CO}_{2}$ if methane fermentation of organic matter is the main digestion process. Methane content decreases below $40 \%$ if air enters and oxidizes methane during fermentation, resulting in much poorer biogas. Although a huge amount of poor biogas is obtainable from landfills, coal mines, and

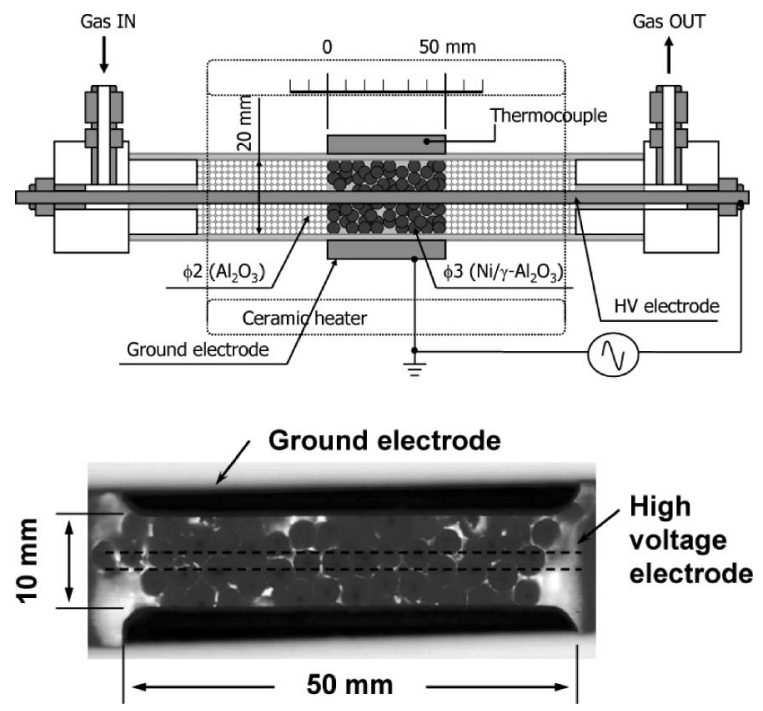

Fig. 3 Schematic Diagram of the DBD-catalyst Hybrid Reactor and an Image of Discharge Running

agricultural residues, most is simply flared and wasted because the global warming potential (GWP) of biogas is 5-15 times as potent as carbon dioxide, depending on methane contents. The poor ignition stability and low heating value of such biogas makes use in a conventional energy utility system extremely difficult. We developed a low-temperature $\left(300-500^{\circ} \mathrm{C}\right)$ method for upgrading simulated biogas using DBD generated in a reforming catalyst bed ${ }^{12), 13), 19) \sim 21)}$. The simulated biogas is partially converted into hydrogen via low-temperature steam reforming; then the hydrogen-enriched biogas is fed into an internal combustion engine. Ignition stability and combustibility of hydrogen enriched biogas were remarkably improved, and the internal combustion engine was powered efficiently. Low-temperature steam reforming is essential so that part of the biogas, with low heating value $\left(20-60 \%\right.$ of $\left.\mathrm{CH}_{4}\right)$, or additional fuel does not have to be used to provide a high-temperature heat source. Low-temperature exhaust gas from an internal combustion engine $\left(300-500^{\circ} \mathrm{C}\right)$ is useful to activate the catalyst bed and heat is partly recovered as chemical energy of hydrogen.

\section{3. Experimental}

Simulated biogas, consisting of $\mathrm{CH}_{4}, \mathrm{~N}_{2}$, and $\mathrm{H}_{2} \mathrm{O}$, was partially reformed in a hybrid reactor using DBD and reforming catalyst $\left(12 \mathrm{wt} \% \mathrm{Ni} / \gamma-\mathrm{Al}_{2} \mathrm{O}_{3}\right)^{19)}$. Commercially available catalysts (ISOP; Süd-Chemie Catalysts Japan, Inc. ${ }^{22)}$ ) were used to maximize the synergistic effect between DBD and the catalyst. A schematic diagram of the hybrid reactor is shown in Fig. 3 . Catalyst pellets ( $3 \mathrm{~mm}$ sphere) were packed in a sapphire tube $\left(\phi_{\mathrm{i}} 20 \mathrm{~mm} \times 50 \mathrm{~mm}\right)$. The catalyst reactor was equipped with an internal high-voltage electrode $\left(\phi_{\mathrm{r}}\right.$ $3 \mathrm{~mm}$ ) and an external grounded electrode. Bipolar pulsed voltage $(+/-20 \mathrm{kV}$ at $1-5 \mathrm{kpps})$ was applied 

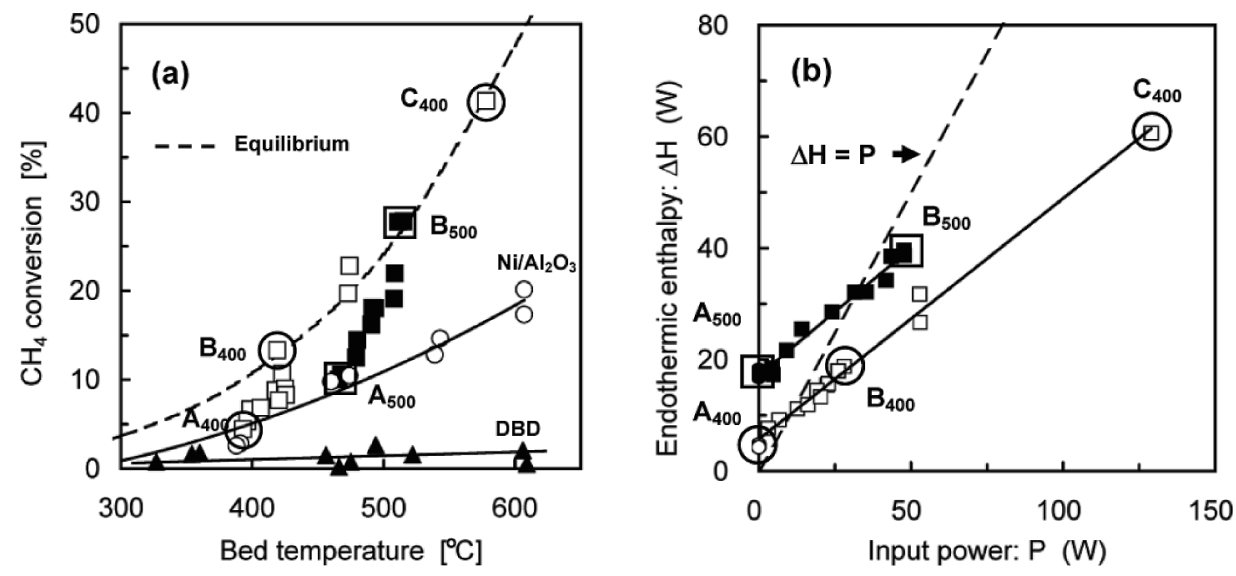

GHSV, 11,500 h ${ }^{-1} ; \mathrm{S} / \mathrm{C}, 1 ; \mathrm{CH}_{4} / \mathrm{N}_{2} / \mathrm{H}_{2} \mathrm{O}, 1100 / 733 / 1100 \mathrm{~cm}^{3} / \mathrm{min} ; \boldsymbol{\Delta}, \mathrm{DBD} ; \bigcirc$, catalyst; $\square$ and $\square$, hybrid; dotted line, equilibrium conversion.

Fig. 4 Synergistic Effect between the Reforming Catalyst and DBD

between the electrodes. Gas breakdown occurred at the pellet contacts where the electric field is concentrated and a number of filamentary discharge channels propagated along the pellet surface. Detailed characteristics of this type of discharge were described previously ${ }^{23)}$. The total gas flow of simulated biogas was adjusted to a gaseous hourly space velocity (GHSV) of 10,000$18,000 \mathrm{~h}^{-1}$.

\section{4. Synergistic Effect between Non-thermal Plasma and Reforming Catalysts}

Figure 4 (a) shows methane conversion in (1) a catalyst bed reactor (without DBD), (2) a hybrid reactor, and (3) a DBD reactor with $\alpha-\mathrm{Al}_{2} \mathrm{O}_{3}$ pellets (without catalysts). The results are plotted with respect to catalyst bed temperature measured using an infrared camera. The dotted line in Fig. 4 (a) represents the equilibrium methane conversion. The relationship between discharge power and endothermic reaction enthalpy is also important parameter because the bed temperature is determined as a result of energy balance. The results for hybrid reactor operation are presented in Fig. 4 (b). Briefly, methane was decomposed only slightly by DBD because the discharge power was minimized, which is possible to avoid excess heating. The main product was $\mathrm{C}_{2} \mathrm{H}_{6}$ and selectivity for hydrogen was much lower than the chemical equilibrium ${ }^{19), 24), 25)}$. The catalyst reaction was more efficient than DBD, but the methane conversion did not reach equilibrium due to low temperature catalysis. On the other hand, methane conversion in the hybrid reactor was clearly much greater than the simple sum of the DBD and catalyst reactions at given bed temperatures.

Methane conversion increased from points $\mathrm{A}_{400}, \mathrm{~B}_{400}$, to $\mathrm{C}_{400}$ depending on the discharge power of $\mathrm{DBD}$, where the subscript denotes the temperature of the ceramic radiant heater, used to externally heat the catalyst bed. The ceramic heater functioned as a constant temperature bath. The bed temperature slightly decreased from the initial condition $\left(400^{\circ} \mathrm{C}\right)$ because of the small amount of heat absorbed by the methane steam reforming when the discharge power was zero (at $\mathrm{A}_{400}$ ) (see Fig. 5 (a)). Methane conversion increased steeply with increasing discharge power, whereas the bed temperature increased slightly $\left(\mathrm{A}_{400} \rightarrow \mathrm{B}_{400}\right)$. The average bed temperature was $420^{\circ} \mathrm{C}$ at $\mathrm{B}_{400}$ (Fig. 5 (b)) and methane conversion reached the chemical equilibrium. A further increase in discharge power created a localized high temperature zone in the downstream portion of the bed (Fig. 5 (c)). After chemical equilibrium was established at $\mathrm{B}_{400}$, further increase in methane conversion beyond the equilibrium was not anticipated because the reverse reaction $\left(\mathrm{CO}_{2}+2 \mathrm{H}_{2} \rightarrow\right.$ $\mathrm{CH}_{4}+2 \mathrm{H}_{2} \mathrm{O}$ ) is much faster than the forward reaction. In the equilibrium-limiting regime, the synergistic effect was no longer anticipated and heat produced by DBD becomes the main driving force for the methane steam reforming ${ }^{20)}$. In fact, the bed temperature increased up to $570^{\circ} \mathrm{C}$ and the equilibrium methane conversion was established at $\mathrm{C}_{400}$. With the initial bed temperature was $500^{\circ} \mathrm{C}$ (at $\mathrm{A}_{500}$ ), the forward methane reaction was also accelerated with input power until the chemical equilibrium was established $\left(\mathrm{A}_{500} \rightarrow \mathrm{B}_{500}\right)$. Excited species, produced by high-energy electron impact, presumably accelerated the low temperature catalysis of methane. Simultaneously, heat produced by DBD promoted the catalytic conversion of methane. Both mechanisms were important in the hybrid reaction. The effects of radical injection and heat generation on the reaction enhancement mechanism was analyzed based on Arrhenius plots.

\section{5. Kinetic Analysis by Arrhenius Plot Method}

The forward methane reaction rate based on the overall steam reforming using power-law kinetics is expressed as Eq. (3). 


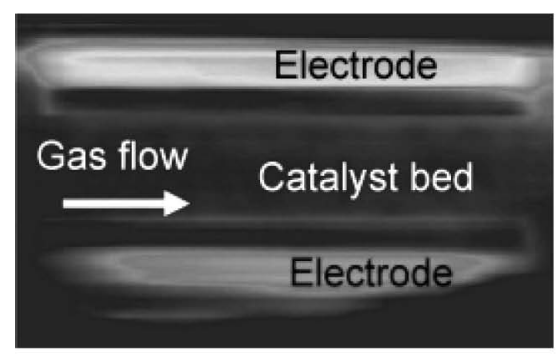

(a) $\mathrm{A}_{400}$ : Electrode temp. $385^{\circ} \mathrm{C}$

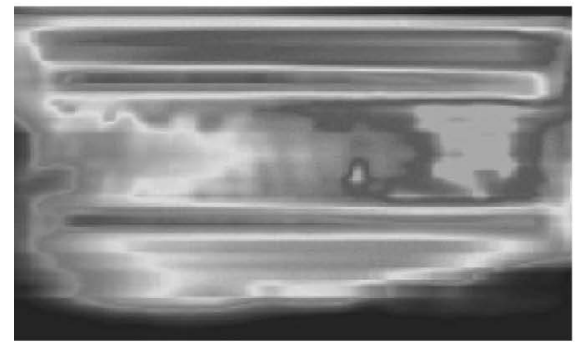

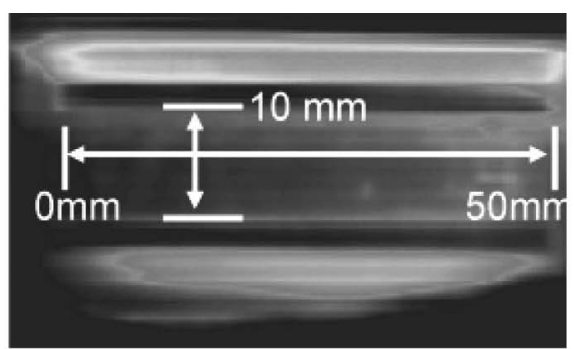

(b) $\mathrm{B}_{400}$ : Electrode temp. $407^{\circ} \mathrm{C}$

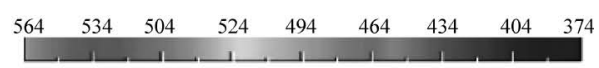

(c) $\mathrm{C}_{400}$ : Electrode temp. $511^{\circ} \mathrm{C}$

Conditions correspond to $\mathrm{A}_{400}, \mathrm{~B}_{400}$, and $\mathrm{C}_{400}$, shown in Figs. 4 (a) and 4 (b), respectively.

Fig. 5 Temperature Distribution of the Catalyst Bed

Table 2 Reaction Orders, Activation Energy, and Pre-exponential Factor of the Overall Methane Steam Reforming Reaction

\begin{tabular}{cccccc}
\hline & $\alpha$ & $\beta$ & $T\left[{ }^{\circ} \mathrm{C}\right]$ & $E\left[\mathrm{~kJ} \cdot \mathrm{mol}^{-1}\right]$ & $A$ \\
\hline Hybrid & 0.54 & 0.20 & $T<420$ & 102 & $\begin{array}{c}3.90 \times 10^{7} \\
{\left[\mathrm{~mol}^{0.26} \cdot \mathrm{L}^{-0.26} \cdot \mathrm{s}^{-1}\right]} \\
\end{array}$ \\
& & & $T>420$ & 53 & $\begin{array}{c}6.15 \times 10^{3} \\
{\left[\mathrm{~mol}^{1.26} \cdot \mathrm{L}^{-0.26} \cdot \mathrm{s}^{-1}\right]}\end{array}$ \\
Catalyst & 0.45 & 0.08 & $T<460$ & 90 & $\begin{array}{c}8.01 \times 10^{5} \\
{\left[\mathrm{~mol}^{1.47} \cdot \mathrm{L}^{-0.47} \cdot \mathrm{s}^{-1}\right]} \\
\end{array}$ \\
& & & $T>460$ & 48 & $\begin{array}{c}8.20 \times 10^{2} \\
{\left[\mathrm{~mol}^{1.47} \cdot \mathrm{L}^{-0.47} \cdot \mathrm{s}^{-1}\right]}\end{array}$ \\
\hline
\end{tabular}

GHSV $=10,800-18,000 \mathrm{~h}^{-1}$ and $\mathrm{S} / \mathrm{C}=1-3$.

$$
r=\frac{\mathrm{d}\left[\mathrm{CH}_{4}\right]}{\mathrm{d} t}=k\left[\mathrm{CH}_{4}\right]^{\alpha}\left[\mathrm{H}_{2} \mathrm{O}\right]^{\beta}
$$

Here, $r$ is the forward methane reaction rate and $k$ is the forward methane reaction rate constant for the overall steam reforming. The reaction order for overall methane steam reforming on nickel catalyst is $\alpha=0.85-1.4$ in $\mathrm{CH}_{4}$ and $\beta=-0.8-0$ in $\mathrm{H}_{2} \mathrm{O}^{26) \sim 29)}$. The phenomenological understanding is that the rate-determining step is the activation of methane on the metallic catalyst, whereas the overall forward reaction rate is less dependent on the $\mathrm{H}_{2} \mathrm{O}$ concentration ${ }^{18)}$. The overall reaction order for $\mathrm{H}_{2} \mathrm{O}(\beta)$ is negative if the metallic catalysts lose activity due to oxidization by $\mathrm{H}_{2} \mathrm{O}$. In the hybrid reactor, both $\mathrm{CH}_{4}$ and $\mathrm{H}_{2} \mathrm{O}$ are excited primarily by electron impact, which is the driving force for modifying the catalytic methane conversion. For this reason, we determined the reaction orders $(\alpha$ and $\beta$ ) independently with and without DBD.

Assuming that the overall rate constant is expressed in Arrhenius form, the results are shown in Fig. 6.

$$
k=A \exp \left(-\frac{E}{R T}\right)
$$

The activation energy $E$ and the pre-exponential factor $A$ for the overall steam reforming reaction are listed in Table 2 along with the respective reaction orders. During the experiment, the discharge power was controlled appropriately so that methane conversion did not reach chemical equilibrium. The detailed numerical procedure to evaluate the reaction orders $(\alpha$ and $\beta$ ), preexponential factor $(A)$ and overall activation energy $(E)$ was described previously ${ }^{20)}$.

The convex nature of the resultant Arrhenius plot implies that the overall steam reforming was in the reaction-limited regime when the bed temperature was 
lower than $460^{\circ} \mathrm{C}$, but transited to the diffusion-limited regime when the bed temperature is higher than $460^{\circ} \mathrm{C}$. An analogous curve is obtained for the hybrid reactor where the rate-determining regime is dominant at $420^{\circ} \mathrm{C}$. Although the overall rate constant in the hybrid reaction was larger than that of the normal catalyst reaction, the overall activation energy was essentially unchanged independently of DBD. The overall activation energy in the reaction-limited regime was approximately $100 \mathrm{~kJ} / \mathrm{mol}$, which agrees well with the reported value $^{18)}$, implying that methane dehydrogenation is the rate-determining step regardless of DBD application. On the other hand, the pre-exponential factor was enhanced by a factor of 50 by DBD. The same trend

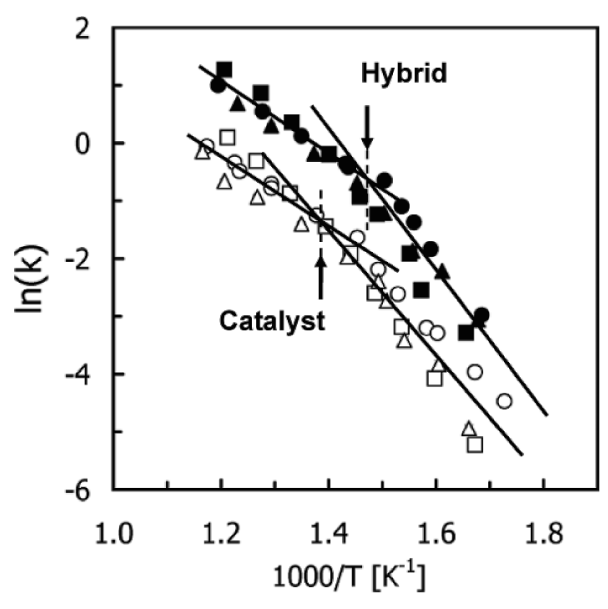

$\mathrm{O}, \mathrm{GHSV}=18,000 \mathrm{~h}^{-1}, \mathrm{~S} / \mathrm{C}=1 ; \square$ $=3 ; \triangle, \boldsymbol{\Delta}, \mathrm{GHSV}=10,800 \mathrm{~h}^{-1}, \mathrm{~S} / \mathrm{C}=1$.

Fig. 6 Arrhenius Plot for Forward Methane Reaction Rate Constant

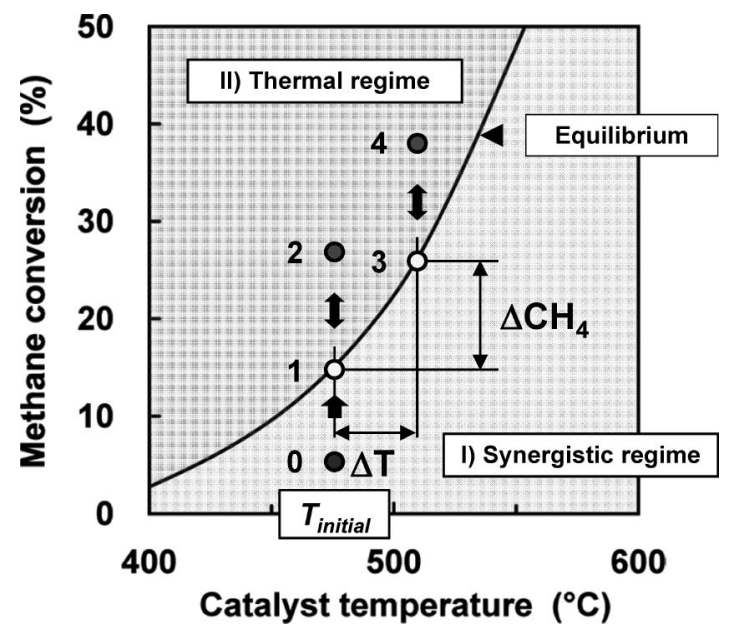

(I) Synergistic effect is possible due to radical injection, (II) Nonthermal plasma is equivalent to heat source due to thermodynamic (equilibrium) limitation.

Fig. 7 Operation Regime of DBD-catalyst Hybrid Reaction was observed in the diffusion-limited regime, where only the pre-exponential factor was enhanced by a factor of 7 , whereas the overall activation energy was not influenced by DBD.

\section{6. Role of Excited $\mathrm{H}_{2} \mathrm{O}$ in Methane Steam Reforming}

To enhance overall methane conversion, both methane dehydrogenation over the solid catalyst and water chemisorption should be promoted simultaneously so that unreacted chemisorbed carbon intermediates are oxidized. Otherwise, chemisorbed carbon ultimately builds up carbon filaments, which block active sites and catalyst pores. In this respect, excited $\mathrm{H}_{2} \mathrm{O}$ is expected to increase the concentration of chemisorbed oxygenrelated intermediates such as $\mathrm{O}$ and $\mathrm{OH}$, and efficiently oxidize chemisorbed solid carbon, leaving sufficient numbers of active sites available for successive methane dehydrogenation. In fact, the reaction order for $\mathrm{H}_{2} \mathrm{O}$ was more than doubled by applying DBD, which eventually increased the pre-exponential factor of the overall forward rate constant $k$. The removal of chemisorbed carbon is a vital reaction pathway together with the methane dehydrogenation reaction. Nevertheless, DBD-induced carbon precipitation was uniquely identified on catalyst pellets ${ }^{21)}$. Therefore, the carbon to steam (S/C) ratio must be increased to prevent carbon formation as reaction temperature increases.

\section{7. Operational Regime of Hybrid Reaction}

The operational regime of the DBD-catalyst hybrid reaction was clearly established, as schematically shown in Fig. 7. In the presence of DBD, methane conversion increases from 0 to 1 , then further increases beyond chemical equilibrium at given temperature $\left(1 \rightarrow 2\right.$ at $\left.T_{\text {initial }}\right)$. However, the excess amount of $\mathrm{CO}_{2}$ and $\mathrm{H}_{2}$ present in the reactor drives the backward reaction $(2 \rightarrow 1)$. This process results in net-zero methane conversion. The energy absorbed by reforming during the $1 \rightarrow 2$ process, which could be either electrical energy or heat, is released as thermal energy through the reverse reaction. This thermal energy simply increases the bed temperature from 1 to 3 . The increase in methane conversion, $\Delta \mathrm{CH}_{4}$ shown in Fig. $\mathbf{7}$, originates from the net temperature increase of the bed. Here again, DBD enhances methane conversion from 3 to 4 ; but reverts to equilibrium through the reverse reaction $(4 \rightarrow 3)$. Even if DBD produces reactive species, the final effect is as a heat source once chemical equilibrium is established and a synergistic effect is no longer anticipated.

\section{Exothermic Reaction System: Direct Methane to Methanol via Partial Oxidation}

\section{1. Introduction}

In this section, direct methane conversion via partial oxidation using a non-thermal plasma combined micro- 


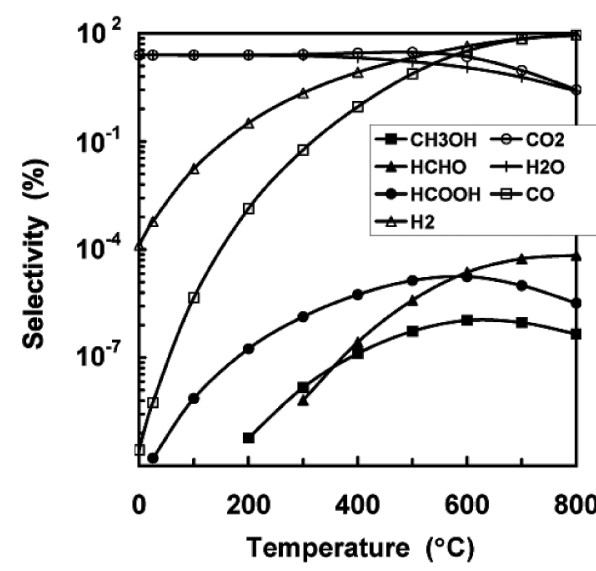

(a)

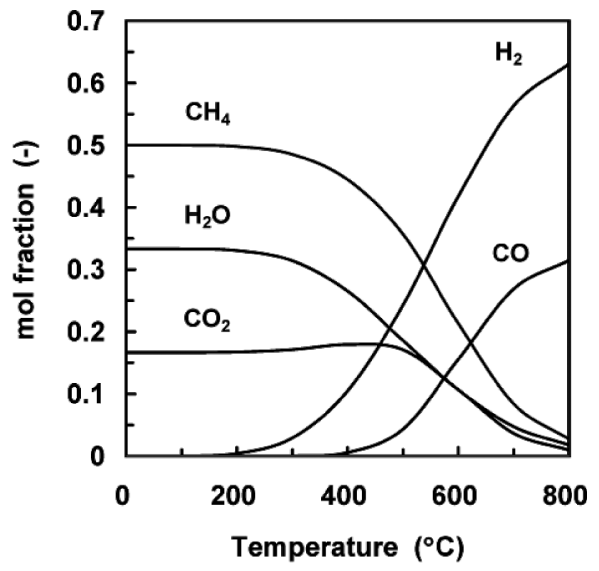

(b)

(a) Product selectivity and (b) mol fraction.

Fig. 8 Equilibrium Composition of $\mathrm{CH}_{4}, \mathrm{O}_{2}$, and Oxidative Products at $101 \mathrm{kPa}$ with $\mathrm{O}_{2} / \mathrm{CH}_{4}=0.5$

reactor, known as a microplasma reactor, is introduced. Microplasmas are an emerging new field of plasma science and technology for materials processing. Many projects are related to chemical vapor deposition, micro fabrication, medical treatment of tissue, decontamination of hazardous biomaterials, lighting, elemental analysis, and so on. In addition, chemical synthesis is important part of electron-driven microchemistry ${ }^{30)}$. Non-thermal plasma "stimulates" the methane-oxygen mixture, leading to spontaneous oxidation of methane into various oxygenates at room temperature, while the heat generated by methane partial oxidation must be removed efficiently so that full combustion of methane is avoided. Unlike methane steam reforming (endothermic reaction) as discussed in the previous section, generation of reactive species at low temperature is the key to achieve direct methane conversion into the desired products at high yields.

\section{2. Background of the Project}

Direct conversion of natural gas into synthetic fuels such as methanol is important because the direct process can reduce the capital and operating costs of the high temperature, energy intensive multi-step processes via syngas production ${ }^{31)}$. Tremendous efforts have been invested in direct methane conversion to oxygenates in homogeneous gas phase reaction and over solid catalysts $^{32) ~ 35)}$, but the yields of desired products has been below economic values ${ }^{36), 37)}$. More recently, atmospheric pressure non-thermal plasma has been suggested as a viable synthesis method because high energy electron impact initiates methane partial oxidation, enabling single step methane conversion into various oxygenates. Nevertheless, the one-pass yield for useful oxygenates was unsatisfactory ${ }^{38) \sim 40)}$. We proposed DBD generated in a microreactor which enabled moderate methane oxidation at room temperature, and selectively produced methanol $\left(\mathrm{CH}_{3} \mathrm{OH}\right)$, formaldehyde ( $\mathrm{HCHO})$, and formic acid $(\mathrm{HCOOH})$ with one-pass yield of more than $10 \%{ }^{41)} 43$. . Use of non-thermal plasma in a microreactor allows application of unconventional thermochemical conditions to materials processing, enabling better control over process parameters for the selective synthesis of desirable products ${ }^{44) \sim 46)}$.

\section{3. Thermodynamic Analysis}

Equilibrium calculations were performed using STANJAN software that solves the adiabatic equilibrium state of gas mixtures based on the JANAF thermochemical database ${ }^{47)}$. Figure 8 shows the equilibrium composition of $\mathrm{CH}_{4}, \mathrm{O}_{2}, \mathrm{CO}, \mathrm{CO}_{2}, \mathrm{H}_{2}, \mathrm{H}_{2} \mathrm{O}, \mathrm{HCHO}$, $\mathrm{CH}_{3} \mathrm{OH}$, and $\mathrm{HCOOH}$, assuming initial $\mathrm{O}_{2} / \mathrm{CH}_{4}=0.5$ at atmospheric pressure $(101 \mathrm{kPa})$. These components were considered based on the experimental results as discussed later. Oxygen $\left(\mathrm{O}_{2}\right)$ is fully consumed even at room temperature. Correspondingly, $50 \%$ of methane is converted, producing full combustion products such as $\mathrm{H}_{2} \mathrm{O}$ and $\mathrm{CO}_{2}$ when the temperature is well below $300^{\circ} \mathrm{C}$. As the temperature increases, the fraction of syngas (i.e. $\mathrm{CO}$ and $\mathrm{H}_{2}$ ) increases and the remaining methane is gradually consumed. Eventually, the $\mathrm{H}_{2}$ / $\mathrm{CO}$ ratio approaches 2 as temperature approaches $800^{\circ} \mathrm{C}$. This reaction scheme expresses the typical two-step methane reforming for syngas production. Liquid components were negligibly small over the temperature range. Thermodynamic analysis emphasizes several important facts: First, to achieve highest selectivity for desired products, abrupt termination of methane oxidation must be achieved at the desired moment before chemical equilibrium is established ${ }^{35), 48)}$. Catalysts can accelerate specific reaction pathways preferentially for better selectivity of the process; but previous results have not been satisfactory ${ }^{36), 37)}$. Nonthermal plasmas can provide a totally different methane 

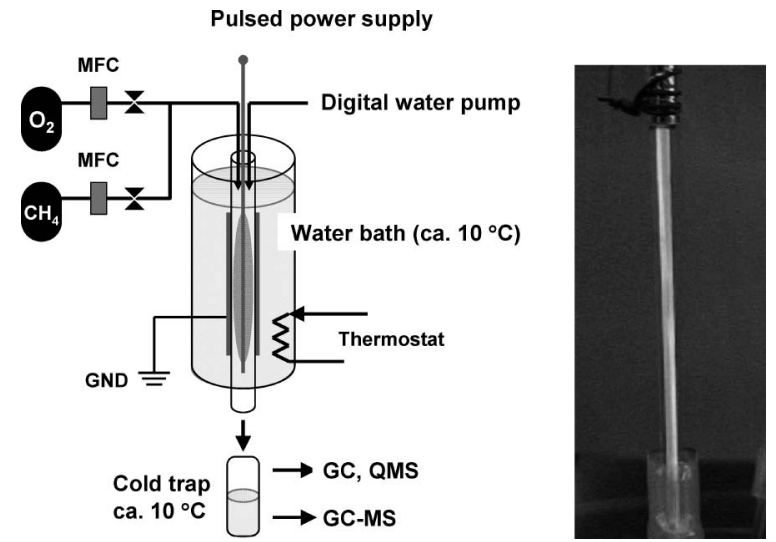

Fig. 9 Schematic Diagram of Microplasma Reactor and Digital Image of Microplasma

activation route with different kinetics in an unusual temperature range, thus providing better feasibility and controllability of partial chemistry instead of the equilibrium state.

\section{4. Experimental}

A detailed description of the microplasma reactor was presented previously ${ }^{49), 50)}$. A schematic diagram of the experimental setup is presented in Fig. 9. The microplasma reactor consists of a quartz tube (I.D: $1.5 \mathrm{~mm}$, O.D. $2.7 \mathrm{~mm}$, length: $50 \mathrm{~mm}$ ) equipped with internal wire electrodes ( $0.5 \mathrm{~mm}$ stainless steel) and an externally grounded electrode. The $\mathrm{CH}_{4}$ and $\mathrm{O}_{2}$ mixture is introduced into the microplasma reactor. The total flow rate is varied so that the reaction time of gas flow is between $100 \mathrm{~ms}$ and $500 \mathrm{~ms}$. A bipolar pulsed high voltage with peak intensity of $10 \mathrm{kV}$ and fixed frequency at $10 \mathrm{kHz}$ is applied between the metallic electrodes. The microplasma reactor is immersed into the water bath maintained near room temperature $\left(10^{\circ} \mathrm{C}\right)$. The microreactor configuration efficiently removes heat generated by methane partial oxidation. Low temperature synthesis is essential because oxygenates are condensed on the microreactor wall which results in product separation from the $\mathrm{O}_{2}$-rich reactive plasma. The idea of product separation is essential because organic oxygenates are much more reactive than methane, and are readily decomposed during plasma activation of methane. Liquid water is also injected intermittently into the microplasma reactor $\left(1.2 \mathrm{~cm}^{3} \cdot \mathrm{min}^{-1}\right.$ for $10 \mathrm{~s}$ and 2 min interval) to wash out condensed oxygenates, which suppresses successive destruction of reactive oxygenates, enabling selective synthesis of oxygenates with high methane conversion in a single reactor.

\section{5. Methane Conversion and Selectivity for Liquid Components}

Figure 10 shows methane conversion with reaction time. The initial $\mathrm{O}_{2} / \mathrm{CH}_{4}$ ratio was also varied. Methane conversion increased linearly with reaction time. Methane steam reforming was also anticipated

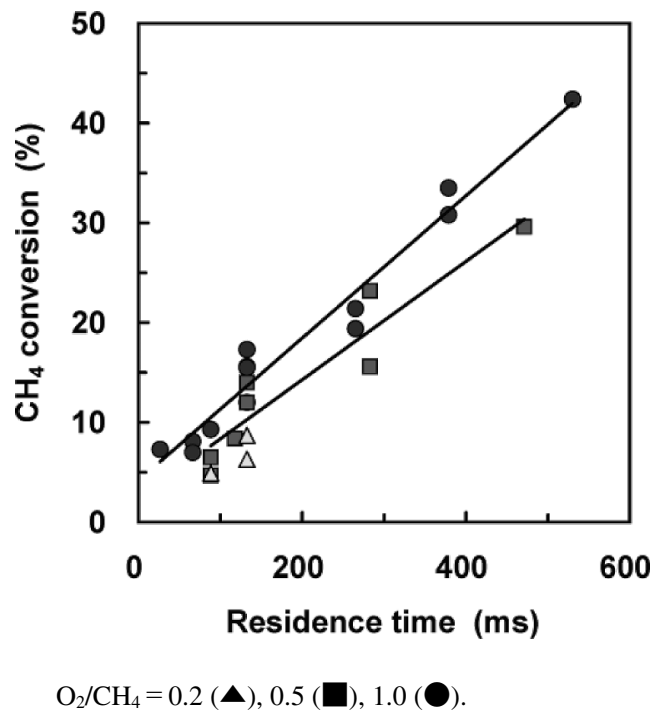

Fig. 10 Methane Conversion vs. Reaction Time

because water vapor was present as a result of liquid water injection. $\mathrm{D}_{2} \mathrm{O}$ was injected to trace the $\mathrm{D}_{2} \mathrm{O}$ (i.e. $\mathrm{H}_{2} \mathrm{O}$ ) dissociation pathway, but neither HD nor $\mathrm{D}_{2}$ were identified by quadrupole mass spectrometry (Prisma-100; Pfeiffer Vacuum Technology AG). Electronic $\mathrm{H}_{2} \mathrm{O}$ dissociation to produce $\mathrm{OH}$, which is a viable radical chain propagator, was anticipated, but did not participate in methane oxidation, as liquid water mechanically washed out condensed oxygenates before further destruction of the desired products occurred. Liquid components were quantitatively analyzed by GC-MS (Shimadzu Corp., QP2010Plus), showing methanol $\left(\mathrm{CH}_{3} \mathrm{OH}\right)$, formaldehyde $(\mathrm{HCHO})$, and formic acid $(\mathrm{HCOOH})$ as the main components.

Selectivity for individual liquid components is described in Fig. 11. Total liquid selectivity was 40$50 \%$ and almost independent of initial $\mathrm{O}_{2}$ content, which implies that product separation due to liquid condensation effectively suppressed excessive oxidation of organic oxygenates. Selectivities for oxygenates and syngas were 5-6 orders of magnitude greater than the chemical equilibrium as shown in Fig. 8, demonstrating that methane oxidation was successfully terminated before the equilibrium was established. The temperature of the microplasma reactor was increased to 300$400^{\circ} \mathrm{C}$ without external cooling. As a result, selectivity for formaldehyde and formic acid decreased dramatically. Selectivity for methanol was surprisingly high in this temperature range.

\section{6. Syngas Production and DME Synthesis as Post Plasma Reaction}

In addition to oxygenates, relatively large amounts of syngas were produced. Figure $\mathbf{1 2}$ shows the $\mathrm{CO}$ and $\mathrm{CO}_{2}$ selectivities and Fig. 13 shows the $\mathrm{H}_{2} / \mathrm{CO}$ ratio. $\mathrm{CO}$ selectivity increased with methane conversion. In contrast, $\mathrm{H}_{2} / \mathrm{CO}$ ratio was independent of methane con- 


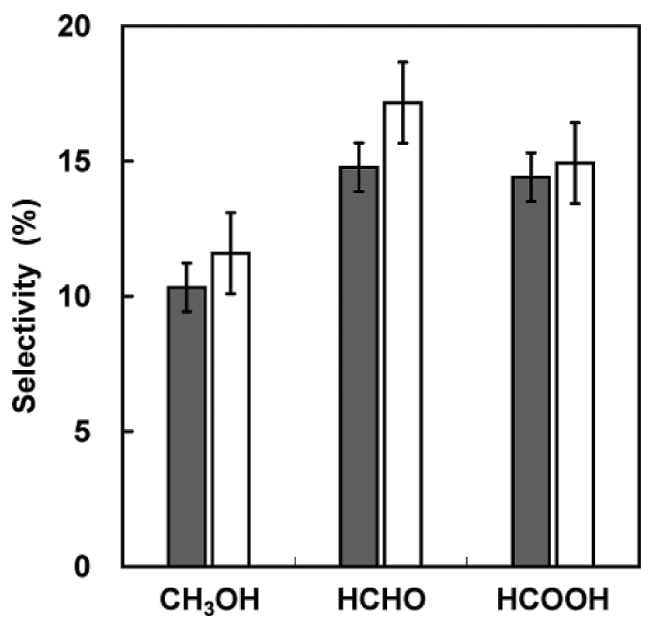

$\mathrm{CH}_{4}: \mathrm{O}_{2}=20: 20 \mathrm{~cm}^{3} \cdot \mathrm{min}^{-1}\left(\mathrm{CH}_{4} \mathrm{conv} .=12.0 \%\right) ; \square 30$ : $15 \mathrm{~cm}^{3} \cdot \mathrm{min}^{-1}$ (8.4\%); Reaction time, $130 \mathrm{~ms}$.

Fig. 11 Selectivity for Oxygenates

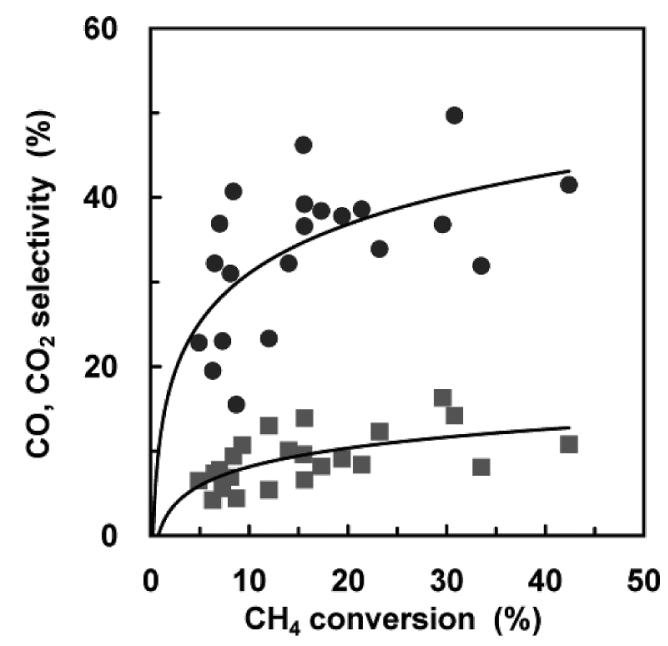

Fig. 12 Selectivity for $\mathrm{CO}(\boldsymbol{)})$ and $\mathrm{CO}_{2}(\boldsymbol{\square})$ at Various Conditions

version, and was determined by the initial $\mathrm{O}_{2} / \mathrm{CH}_{4}$ ratio. Small amounts of oxygen, such as $\mathrm{O}_{2} / \mathrm{CH}_{4}=0.2$, produced hydrogen rich syngas $\left(\mathrm{H}_{2} / \mathrm{CO}=1.8\right)$, but formation of a tar-like product was observed on the reactor wall. Note that solid carbon formation was fully eliminated because of low temperature synthesis and the absence of metallic catalysts. Syngas is the fundamental building block for $\mathrm{C}_{1}$ chemistry, and is readily converted into various chemicals under moderate conditions using well-established catalysts. We assume that one-pass dimethyl ether synthesis (DME; $\mathrm{CH}_{3} \mathrm{OCH}_{3}$ ) from syngas with $\mathrm{H}_{2} / \mathrm{CO} \sim 1^{51)}$ occurred as a post plasma reaction, given by,

$$
3 \mathrm{CO}+3 \mathrm{H}_{2}=\mathrm{CH}_{3} \mathrm{OCH}_{3}+\mathrm{CO}_{2}
$$

When initial $\mathrm{O}_{2} / \mathrm{CH}_{4}=0.5$, syngas with $\mathrm{H}_{2} / \mathrm{CO} \sim 1.2$ was obtained. Eventually, overall liquid selectivity, $S_{\text {total }}=S_{\text {liq }}+S_{\text {DME }}$, would be feasible:

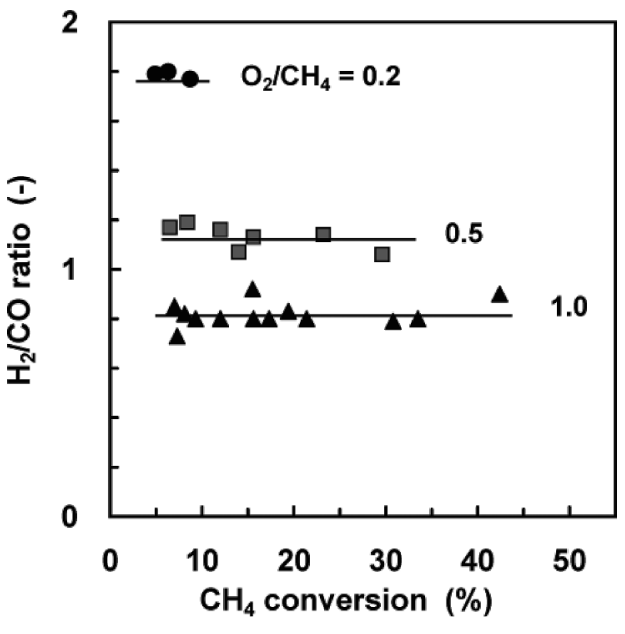

$\mathrm{O}_{2} / \mathrm{CH}_{4}=0.2, \mathbf{\square} ; 0.5, \mathbf{\Delta} ; 1.0$.

Fig. $13 \mathrm{H}_{2} / \mathrm{CO}$ Ratio vs. Methane Conversion

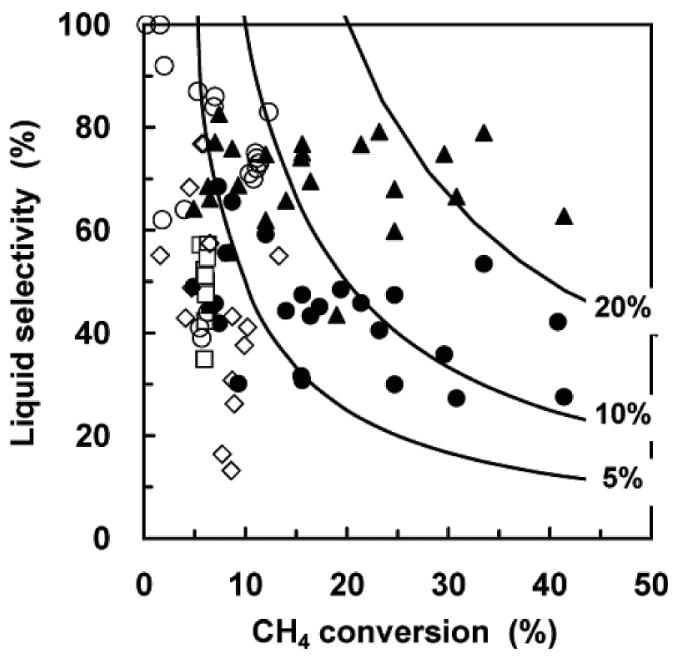

Conditions, $\mathrm{O}_{2} / \mathrm{CH}_{4}, 0.5$ and 1.0; Reaction time, 130-530 ms, Three curves represent constant yield lines. Hollow symbols are literature values; $\square$ Bjorklund $^{33)}, \bigcirc$ Feng $^{34)}, \diamond$ Yarlagadda $^{35)}$.

Fig. 14 Liquid Selectivity $\left(S_{\text {liq }}\right.$ and $\left.\boldsymbol{\Delta} S_{\text {total }}\right) v$ s. Methane Conversion

$$
\begin{aligned}
& S_{\mathrm{liq}}=\left[\mathrm{CH}_{3} \mathrm{OH}\right]_{\mathrm{sel}}+[\mathrm{CHOH}]_{\mathrm{sel}}+[\mathrm{HCOOH}]_{\mathrm{sel}} \\
& S_{\mathrm{DME}}=\frac{2}{3} \times[\mathrm{CO}]_{\mathrm{sel}}(n>1) \\
& S_{\text {total }}=S_{\mathrm{liq}}+S_{\mathrm{DME}}
\end{aligned}
$$

\section{7. Comparison with Conventional Thermo- chemical Methods}

Figure 14 shows the selectivities for liquid components ( $S_{\text {liq }}$ and $\left.S_{\text {total }}\right)$ with respect to methane conversion obtained for a wide spectrum of operating conditions and compared with three conventional thermochemical methods. The conventional methods required addition 
of relatively high temperature thermal energy to initiate methane oxidation, whereas small amounts of oxygen, typically $10 \%$ at most, were introduced so that successive oxidation of methanol was suppressed. Effective cooling methods, such as the water bath used in this study, could not be used because low temperature conditions do not initiate methane oxidation. As a result, methane conversion beyond $10 \%$ was hardly achieved. Methane conversion was increased by increasing either oxygen content or reaction temperature, but the selectivity for useful oxygenates dropped sharply. In our method, liquid product selectivity is slightly decreased with methane conversion, implying that liquid product separation is effective in the microplasma reactor. Although one-pass liquid yield reaching $20 \%$ is obtainable, liquid selectivity was below $60 \%(0)$. Assuming post DME synthesis with the given syngas $\left(\mathrm{H}_{2} / \mathrm{CO} \sim\right.$ 1), the overall liquid selectivity can be enhanced to $80 \%$ (A).

\section{Conclusions and Future Trends}

This review article introduced the principle of plasma fuel reforming, followed by two contrasting examples of non-thermal plasma catalysis of methane. Two major conclusions were derived: First, only non-thermal plasmas might be an inefficient way of converting methane due to the large activation energy required for the electron impact process. Second, appropriate combinations of thermal energy (including heat removal) and radical species produced by non-thermal plasma can establish efficient fuel reforming. Both radical species and thermal energy are required for efficient methane conversion in methane steam reforming. Combination of reforming catalysts minimizes the discharge power required for low temperature methane steam reforming, but methane conversion as well as product distribution are dominated by the chemical equilibrium under given conditions. In contrast, methane partial oxidation by radical injection at room temperature is the key to achieve high methanol yields where the product distribution is highly non-equilibrium. In addition to radical injection, efficient heat removal using a microreactor configuration is crucial.

Hydrogen energy and related technology such as the PEFC (Polymer Electrolyte Fuel Cell) and FCV (Fuel Cell Vehicle) have motivated research activity in onboard plasma fuel reforming. However, mass production of high purity hydrogen $(\mathrm{CO}<10 \mathrm{ppm})$ is hard to achieve in an economical way. On the other hand, fuel modification by plasma catalysis for the SOFC (Solid Oxide Fuel Cell) would be feasible because the initial feedstock does not need to be modified entirely. Hydrogen enrichment of poor bio-resources by nonthermal plasma, introduced in section 3., is also feasible because initial feedstocks are partially converted into hydrogen that greatly reduce electrical energy requirements, whereas the combustion capability of poor biogas is sufficiently improved as a result of hydrogen enrichment. Note that in principle, biogas is carbon neutral. Plasma-assisted combustion of landfill gas, which emits methane under extremely fuel-lean conditions, is interesting because the global warming potential (GWP) of landfill gas is 10 times as potent as that of carbon dioxide. Development of a portable plasma reactor may be beneficial to burn trace amounts of residual hydrogen in a fuel cell exhaust for safety purposes. Direct methane to methanol conversion using DBD has a relatively long research history, but adequate yield has not been achieved yet. The combination of DBD and a microreactor enables excellent control over heat and mass transport in the discharge field, enabling direct methanol synthesis at high yield. Much research regarding plasma fuel conversion is ongoing on the laboratory scale worldwide, but we have to be aware that plasma fuel conversion is a part of the energy utility system. Even if the energy efficiency of a plasma reactor is not as excellent as existing technology, the overall energy and material conversion efficiency of the system could be enhanced because the plasma can broaden the operation window of the system, and enables chemical reaction under unconventional situations. Further development of plasma fuel reforming has excellent potential to eventually provide viable solutions for future energy and material use.

\section{Acknowledgments}

The authors would like to thank former postdoctoral researcher Dr. Shigeru Kado (Chiyoda Corporation), Dr. Sreejit Nair (Dow Chemicals International) and Dr. Anıl Ağıral (Lawrence Berkeley National Laboratory), and Dr. Valentin Goujard (currently JSPS PD fellow) for supporting the projects. Projects were partly supported by KAKENHI, Japan.

\section{References}

1) Gutsol, A., "Handbook of Combustion," Vol. 5 New Technology, Wiley-VCH, (2010), p. 323.

2) Chen, H. L., Lee, H. M., Chen, S. H., Chao, Y., Chang, M. B., Appl. Catal. B: Environmental, 85, 1 (2008).

3) Petitpas, G., Rollier, J.-D., Darmon, A., Gonzalez-Aguilar, J., Metkemeijer, R., Fulcheri, L., Int. Hydrogen Energy, 32, 2848 (2007).

4) Kim, H.-H., Plasma Processes and Polymers, 1, 91 (2004).

5) Kado, S., Sekine, Y., Nozaki, T., Okazaki, K., Catal. Today, 89, (1-2), 47 (2004).

6) Fincke, J. R., Anderson, R. P., Hyde, T., Detering, B. A., Wright, R., Bewley, R. L., Haggard, D. C., Swank, W. D., Plasma Chemistry and Plasma Processing, 22, 105 (2002).

7) Gaudernack, B., Lynum, S., Int. Hydrogen Energy, 23, 1087 (1998).

8) Czernichowski, A., Pure and Applied Chemistry, 66, (6), 1301 (1994).

9) Kalra, C. S., Cho, Y. I., Gutsol, A., Fridman, A., Rufael, T. S., 
Review of Scientific Instruments, 76, (2), 025110 (2005).

10) Kogelschatz, U., Plasma Chemistry and Plasma Processing, 23, 1 (2003).

11) Nozaki, T., Unno, Y., Okazaki, K., Plasma Sources Science \& Technology, 11, 431 (2002).

12) Nozaki, T., Muto, N., Kado, S., Okazaki, K., Catal. Today, 89, 57 (2004)

13) Nozaki, T., Muto, N., Kado, S., Okazaki, K., Catal. Today, 89, 67 (2004)

14) Wliasson, B., Hirth, M., Kogelschatz, U., J. Phys. D: Appl. Phys., 20, 1421 (1987).

15) Davies, D. K., Kline, L. E., Bies, W. E., J. Appl. Phys., 65, 3311 (1989).

16) Morgan, W. L., Penetrante, B. M., Comp. Phys. Comm., 58, 127 (1990).

17) Tsang, W., Hampson, R. F., J. Phys. Chem. Ref. Data, 15, 1087 (1986) .

18) Wei, J., Igrlesia, E., J. Catal., 224, 370 (2004).

19) Nozaki, T., Tsukijihara, H., Okazaki, K., Energy \& Fuels, 20, 339 (2006).

20) Nozaki, T., Tsukijihara, H., Fukui, W., Okazaki, K., Energy \& Fuels, 21, 2525 (2007).

21) Nozaki, T., Fukui, W., Okazaki, K., Energy \& Fuels, 22, 3600 (2008).

22) http://www.sud-chemie-jp.com/ (consult on Nov 2010).

23) Gibalov, V. I., Pietsch, G. J., J. Phys. D: Appl. Phys., 33, 2618 (2000).

24) Hammer, T., Kappes, T., Schiene, W., Utilization of Greenhouse Gases - ACS Symposium Series, ed. by Liu, C.-J. et al., 852, 292 (2003).

25) Sekine, Y., Asai, S., Kado, S., Matsukata, M., Kikuchi, E., Chem. Eng. Sci., 63, 5056 (2008).

26) Lee, A. L., Zabransky, R. F., Ind. Eng. Chem. Res., 29, 766 (1990).

27) Rostrup-Nielsen, J. R., Bak Hansen, J.-H., J. Catal., 144, 38 (1993).

28) Ahmed, K., Foger, K., Catal. Today, 63, 479 (2000).

29) Laosiripojana, N., Assabumrungrat, S., Appl. Catal. A: General, 290, 200 (2005).

30) Ağıral, A., Gardeniers, Han, J. G. E., Advances in Chemical Engineering, 38, 37 (2010).

31) Periana, R. A., Mironov, O., Taube, D., Bhalla, G., Jones, C. J., Science, 301, 814 (2003).
32) Bjorklund, M. C., Carr, R. W., Eng. Chem. Res., 41, 6528 (2002).

33) Feng, W., Knopf, F. C., Dooley, K. M., Energy \& Fuels, 8, 815 (1994).

34) Yarlagadda, P. S., Morton, L. A., Huntera, N. R., Gesser, H. D., Ind. Eng. Chem. Res., 27, 252 (1998).

35) Danen, W. C., Ferris, M. J., Lyman, J. L., Oldenborg, R. C., Rofer, C. K., Steit, G. E., Prepr. Pap.-Am. Chem. Soc., Div. Petro. Chem., 36, 166 (1991).

36) Casey, P. S., McAllister, T., Foger, K., Ind. Eng. Chem. Res., 33, 1120 (1994).

37) Ohtsuka, K., Wang, Y., Appl. Catal. A: General, 222, 145 (2001).

38) Larkin, D. W., Lobban, L. L., Mallinson, R. G., Catal. Today, 71, 199 (2001)

39) Okazaki, K., Kishida, T., Ogawa, K., Nozaki, T., Energy Conv. Manage., 43, 1459 (2002).

40) Zhou, L. M., Xue, B., Kogelschatz, U., Eliasson, B., Plasma Chem. Plasma Process., 18, 375 (1998).

41) Nozaki, T., Hattori, A., Okazaki, K., Catal. Today, 98, 607 (2004).

42) Nozaki, T., Kado, S., Hattori, A., Okazaki, K., Muto, N., Stud. Surf. Sci. Catal., 147, 505 (2004).

43) Nozaki T., Ağıral, A., Nakase, M., Okazaki, K., Kokai Tokkyo Koho JP 11-001322 (2011).

44) Trionfetti, C., Ağıral, A., Gardeniers, Han, J. G. E., Lefferts, L., Seshan, K., Chem. Phys. Chem., 9, 533 (2008).

45) Trionfetti, C., Ağıral, A., Gardeniers, Han, J. G. E., Lefferts, L., Seshan, K., J. Phys. Chem. C, 112, 4267 (2008).

46) Ağıral, A., Groenland, A. W., Chinthaginjala, J. K., Seshan, K., Lefferts, L., Gardeniers, Han, J. G. E., J. Phys. D: Appl. Phys., 41, 194009 (2008).

47) Reynolds, W. C., "The Element Potential Method for Chemical Equilibrium Analysis: Implementation in the Interactive Program STANJAN," Tech. Rep. Stanford Univ., (1986).

48) Sekine, Y., Fujimoto, K., Energy \& Fuels, 10, 1278 (1996).

49) Nozaki, T., Ağıral, A., Yuzawa, S., Gardeniers, Han, J. G. E., Okazaki, K., Chem. Eng. J., 166, 288 (2011).

50) Ağıral, A., Nozaki, T., Yuzawa, S., Nakase, M., Okazaki, K., Gardeniers, Han, J. G. E., Chem. Eng. J., 167, 560 (2011).

51) Shikada, T., Miyoshi, Y., Mogi, Y., Inoue, N., Ohno, Y., Stud. Surf. Sci. Catal., 172, 137 (2007). 
要旨

\title{
大気圧非平衡プラズマを用いた新規なメタン転換技術の開発
}

\author{
野崎 智洋, 岡崎 健
}

東京工業大学大学院理工学研究科機械制御システム専攻, 152-8552 東京都目黒区大岡山2-12-1

化石燃料利用体系の省エネルギー, 省資源, $\mathrm{CO}_{2}$ 排出抑制が 求められている。現在は, 熱化学的手法を基盤としたエネル ギー・物質変換が主要な役割を果たしているが, 長期的なエネ ルギー資源利用体系のあり方を考えたとき，既成技術の延長線 上にない革新的な反応プロセスの開発が不可欠である。このよ うな背景から, 我々は大気圧非平衡プラズマを利用して, 天然 ガスやバイオガスの主成分であるメタンを高効率に転換するた めの技術を開発している。本稿では一般的なプラズマ燃料改質 の概要を述べた後, これまで我々が取り組んできた研究を二つ
紹介する。まず，プラズマ-触媒ハイブリッド反応を用いた低 温メタン水蒸気改質について概要を述べた後, マイクロプラズ マによるメタンからメタノールの常温直接合成を紹介する。そ れぞれ，具体的な応用を目指したプラズマ燃料改質の位置づけ を明確にした後, プラズマ固有の反応特性，たとえばプラズマ と触媒のシナジー効果, マイクロプラズマによる高度に非平衡 化された化学反応場の創成など, 将来の革新的技術開発につな がると期待される新しい技術の概要を紹介する。最後にプラズ マ燃料改質の展望を述べて本稿のくくりとする。 